\title{
All eyes north
}

\section{The Arctic - particularly Greenland - needs to become a major focus of research for years to come.}

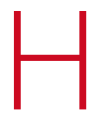
alfway through the International Polar Year (IPY), which actually stretches from March 2007 to March 2009, it is clear that polar research has received exactly the kind of boost that its planners were seeking. As of last month, more than 160 projects were under way with full or partial funding. Some 60 countries are involved, including such unexpected ones as Portugal and Iran.

Public outreach has been particularly successful, with children and students getting involved in polar celebrations, video links to researchers in the field and websites. The ranks of polar artists are swelling with painters, sculptors and even a puppeteer. There are IPY stamps and IPY coins, and Sweden has made toilet paper with the IPY logo on it.

More seriously, several multidisciplinary, multinational projects have now begun. Europe is deep in the throes of planning its icebreakercum-drillship, the Aurora Borealis, for launch in 2014. Denmark has started its next Greenland ice-core drilling project. In Antarctica, teams have drilled through the ice shelf to the sediment below, and others are planning an assault on the buried Gamburtsev Mountains.

Yet for all this apparent vigour, major problems remain for polar research - chief among them funding. A number of IPY-approved projects struggled to get off the ground last year, as money for them was slow to come from national governments. This includes the US National Science Foundation (NSF), the powerhouse of polar research, which was hamstrung by, among other things, the late approval by Congress of its 2008 budget.

Some money is now flowing. According to IPY managers, around $\$ 400$ million in new funds is being distributed across the entire IPY; added to the $\$ 800$ million that would normally be spent worldwide on polar research during that time, they argue it's like getting three years' funding in two years.

But that doesn't solve the tougher issue of how resources should be allocated. With its long tradition as the scientific continent, Antarctica has historically drawn the lion's share of funding. The NSF, for instance, spends about $\$ 325$ million on the continent annually, largely to maintain its massive research infrastructure there. Arctic sciences, in contrast, get about $\$ 100$ million.

Attention needs to shift northwards, and fast. The precise north-south balance can certainly be debated. But consider how surprised researchers have been by the sudden and dramatic shrinking of the Arctic sea ice in recent summers. That fact alone signals that more monitoring and modelling is needed to understand what might happen next.

The most pressing Arctic question concerns the future of the Greenland ice sheet (see page 798). Too little attention is paid to monitoring its ice loss each summer and modelling what
"The entire polarresearch community needs to come together to monitor Greenland's meltdown on a comprehensive scale." that might mean for the future. In total, Greenland's ice could raise the sea level by 7 metres - far less than the 21 metres locked in Antarctica, but far closer to complete meltdown. Yet Greenland gets just \$10.5 million annually of NSF money - \$9 million of which goes on logistics. Denmark pours twice that amount in, but it is still not enough.

Currently, a handful of individually motivated researchers heroically rush to the island each summer to set up monitoring stations. They capture the jerky motions of the massive outlet glaciers that are dumping Greenland's ice into the sea, and videotape the huge meltwater lakes that form on the ice sheet each summer and then drain away into oblivion. They patch together data from a motley collection of remote-sensing satellites, trying to capture the changes in Greenland's ice as they happen.

But they can only do so much. The entire polar-research community needs to come together to monitor Greenland's meltdown on a comprehensive scale. In the best of worlds, the IPY would open the eyes of those who control the purse strings to the need for more Arctic monitoring. Members of the US Congress, for one, have been happily signing up for trips to the South Pole and to Summit Station atop Greenland. It remains to be seen whether those visits will make any difference when it comes to Congress voting on money for the NSF - or whether the NSF would even choose to give more money to its Office of Polar Programs given the competing demands on its resources. But it is time to spend more on Greenland, and to think more about Greenland, and to make sure this continues for years to come.

\section{A ghost of battles past}

\section{The US veterans' administration should go ahead with a much-delayed study of Agent Orange.}

ven by government standards, a near 30-year delay in getting a study approved is extreme. But that is essentially what has happened with a proposed large-scale epidemiological study of the possible effects of the defoliant Agent Orange and other combat factors on US veterans of the Vietnam War. This US administration, or the next, would do well to heed the advice issued last month by the National Academy of Sciences that such a study should now proceed.

The academy argues that new data, and advances in geographical information systems (J. M. Stellman et al. Nature 422, 681-687; 2003), could plug a significant gap in earlier epidemiological studies (see page 786). Today, a study should be able to provide key information about when and where troops were exposed to the defoliant, which contained highly toxic compounds called dioxins. And advances in computing and databases mean that the study would cost a fraction of earlier estimates. 
The question is whether the US Department of Veterans Affairs (VA) will cooperate. In the 1980s, pilot studies by the VA and several other government agencies found little evidence for a link between Agent Orange and veterans' health problems. They concluded that poor data made doing the large-scale study requested by Congress in 1979 impossible. The VA has been sceptical of the health claims ever since. But critics questioned the independence of those studies. So in 1991, Congress asked the National Academies to assess both the evidence for the health links and the feasibility of full-blown epidemiological studies. It disagreed with the previous analysis, saying that a large-scale study was indeed feasible. But there matters have stood ever since. An independent study cannot happen until the VA provides the funding - which has not been forthcoming.

It is time to stop stalling. It is true that veterans would not be the first choice for a study on the toxicity of herbicides and dioxins - better-documented accidental exposures would be preferable. But that misses the point. The proposed study is both a legitimate research opportunity and a moral imperative. There are privacy issues with medical and other records, but these are not insurmountable. And even if the data and science are not perfect, the new models and techniques can be refined. A lot of data on some 3 million veterans

\section{Broken promises}

\section{Efforts to boost science in the Islamic world need financial commitment from the nations themselves.}

$\Lambda$ s part of the biggest shake-up of science and technology governance in two decades, the 57-member Organisation of the Islamic Conference (OIC) last month designated COMSTECH - its committee of science ministers - as its official agency for overseeing science. As a result, COMSTECH will now play an active part in the OIC's ten-year plan for modernization.

The OIC's member states are among the world's lowest producers of patents and research papers. According to the organization's own data, scientists from Islamic-majority countries contributed just 2.5\% of articles in peer-reviewed journals between 1995 and 2005.

The OIC's long-term goal is to turn this situation around completely. It wants to see at least 20 OIC universities joining the world's top 500 - there are currently none. It is also planning a new centre for science and innovation policy, and a new network of centres of research excellence. As well as improving access to capital for technology start-ups, the OIC's plans aim to boost the capacity of industry to produce more vaccines, affordable cars and planes, and to increase collaborations with scientists and organizations outside the OIC world.

COMSTECH will share the responsibility for implementing these changes with the OIC secretariat's newly revived science and technology office in Jeddah, and with the Islamic Development Bank, which has allocated $10 \%$ of its grants and loans for science and technology. Strategic guidance and oversight will come from a task force that includes the OIC secretary-general, Ekmeleddin Ihsanoglu, a science historian from Turkey, and the chemist Atta-ur-Rahman from Pakistan, who heads the COMSTECH secretariat. are already sitting in the government's databases - or in some cases are gathering dust, undigitized, on its shelves. Cleaning up and tying those data together would itself be valuable archival housekeeping, and would aid research.

The process would also benefit the VA. More eyes on the data would stimulate creativity, and a greater involvement of outside researchers would bolster credibility and public acceptance of the study's results. This is particularly crucial following the debate over 'Gulf War syndrome', in which government studies lasting more than a decade failed to properly identify or exclude debilitating war-related illnesses in veterans from the first Gulf War. With an increasing number of soldiers from the current war reporting symptoms of post-traumatic stress disorder, it is essential that the VA includes external scientific input as early as possible in the process of helping to treat them.

And there is a bigger picture. US veterans are not the only ones suffering as a result of the Vietnam War. So scientists and the US and Vietnamese governments need to revive stalled bilateral collaborations (see Nature 434, 687; 2005) on the health effects of Agent Orange on the Vietnamese population itself. The responsibilities of warfare do not end on the battlefield, nor can they be limited by the battle lines that once divided friend from foe.

The plans are ambitious and impressive, and deserve the wholehearted support of the OIC's member states. But the big test now is whether that support will be forthcoming. In principle, money should not be a problem: OIC member states include some of the wealthiest nations in the world. Unlike other wealthy states, however, they allocate less than $0.5 \%$ of their gross domestic product to research and development.

Related to this is the fact that the member states have a reputation inside the OIC for not delivering on their promises. Witness the controversy over COMSTECH's existing budget. For the fiscal year 2006-7, ministers approved a budget of US\$18 million for COMSTECH's work. But only $\$ 7$ million came through, including $\$ 2.3$ million from the Islamic Development Bank and \$2.6 million from member states. Of this, COMSTECH's host country, Pakistan, contributed $\$ 2$ million. Twelve of the other 56 countries contributed a mere $\$ 600,000$ between them. The rest promised much, but gave nothing.

One of the reasons for these broken promises is that, until now, a decision made by a science minister at a COMSTECH meeting has carried little or no weight in that minister's national parliament, or with his or her finance minister. COMSTECH's new status as an official body of the OIC should begin to change this. Jordan, Iran, Pakistan and Saudi Arabia have promised new money, and, for the first time, COMSTECH ministers will be able to stand before heads of state and call to account those who do not deliver.

Of course, it will still be possible for any member state to make a commitment and then completely ignore it. But such states need to understand that plans to upgrade universities or build affordable cars need a massive injection of new money. And they must appreciate that OIC institutions created to deliver those promises must be adequately funded. The OIC is right to engage the private sector and development banks in efforts to reform science and technology, but public institutions must also play their part. 